\title{
Preventive potential of Andrographis paniculata-derived compounds in metabolic syndrome-associated prostate cancer: A narrative review on the mechanism of action
}

\author{
Mohamad Khairul Hafiz Idris, Rosnani Hasham* \\ Department of Bioprocess and Polymer Engineering, School of Chemical and Energy Engineering, Faculty of Engineering, Universiti Teknologi Malaysia, \\ Skudai, Malaysia.
}

\begin{tabular}{l}
\hline ARTICLE INFO \\
\hline Received on: $27 / 01 / 2021$ \\
Accepted on: $17 / 03 / 2021$ \\
Available online: $05 / 08 / 2021$ \\
\\
\hline Key words: \\
Prostate cancer, metabolic \\
syndrome, Andrographis \\
paniculata, adiposity, \\
hyperglycemia.
\end{tabular}

\begin{abstract}
Metabolic syndrome (MetS) and prostate cancer (PCa) are among the diseases with a concerning prevalence. The reported cases for both medical dilemmas have been steady with no sign of abating at the moment. More worrying is that researchers have started to discover that some of the components of MetS associatively worsen the prognosis of PCa. Even though the relationship is not fully known, its manifestation could cause extra burden to the currently implemented treatment approaches. The use of plant bioactive compounds as an alternative treatment has gained recognition, provided that its mechanisms of action, tolerability, efficacy, safety, and cost-effectiveness are well understood. Therefore, the current review intended to highlight the potential of bioactive compounds derived from plants to simultaneously target MetS, PCa, and MetS-PCa codisease. Additionally, emphasis on the potential of Andrographis paniculata (AP) as a candidate for the treatment of MetS-PCa is also highlighted.
\end{abstract}

\section{INTRODUCTION}

The prevalence of prostate cancer $(\mathrm{PCa})$ is increasing in our community. In Asian regions, the incidence of PCa has been on the rise from $5 \%$ in 1978 to $118 \%$ in 1997 in the indexed countries (Sim and Cheng, 2005), and there is no sign of this trend abating. At present, $\mathrm{PCa}$ is the sixth most frequent cancer among Asian men (Chen et al., 2014). In other regions, similar trends have also been reported. $\mathrm{PCa}$ is among the top contributors that make up half of the overall burden of cancer in Europe in 2018 (Ferlay et al., 2018). In a recent report published by the Ministry of Health of Malaysia, 3,132 cases were reported between 2007 and 2011. Following that, between 2012 and 2016, the total reported case increased to 4,189 (Azizah et al., 2019). It is expected that by 2030, 1.7 million new PCa cases and 499,000 deaths will occur in

\section{${ }^{*}$ Corresponding Author}

Rosnani Hasham, Department of Bioprocess and Polymer Engineering, School of Chemical and Energy Engineering, Faculty of Engineering, Universiti Teknologi Malaysia, Skudai, Malaysia.

E-mail: r-rosnani@utm.my the entire world, and this cancer will be the most common in men in the future (Pakzad et al., 2015).

The development of PCa is multifactorial. However, it has been observed that the progression is worse among individuals with metabolic syndrome (MetS), which comprises a series of systemic dysfunctions including high adiposity, hyperglycemia, hypertension, and dyslipidemia. A meta-analysis conducted on previously published academic manuscripts found that MetS was associated with a $12 \%$ increase in PCa risk. However, the association was only significant in the studies conducted in Europe but not in those in the USA and Asia. The same report also emphasized that hypertension and waist circumference of $>102 \mathrm{~cm}$ were associated with a significantly higher risk of $\mathrm{PCa}$ at $15 \%$ and 56\%, respectively (Esposito et al., 2013). Nevertheless, another meta-analysis reported that men with MetS have a lower relative risk to develop $\mathrm{PCa}$ and its associated mortality. Yet, the same report highlighted that men with MetS are more likely to suffer from high-grade $\mathrm{PCa}$ and more advanced disease, and they are also at a greater risk of disease progression after radical prostatectomy and are more likely to succumb to PCa-specific death (Xiang et al., 2013). 
One of the mediators between MetS and PCa is the high level of hormones and cytokines secreted by adipocytes. An earlier study reported that long-term exposure to high leptin levels significantly worsens PCa prognosis (Noda et al., 2015). Additionally, the action of leptin is more pronounced in the androgen-resistant PCa cells (Hoda et al., 2012). As such, the treatment approach using leptin antagonist has gained a great amount of research interest. For example, a leptin antagonist Leu-Asp-Phe-Ile (LDFI) has been successfully derived from amino acids and it was discovered to have growth and migration inhibitory effects on breast cancer cells after further testing in an animal model (Catalano et al., 2015). Additionally, plant-derived leptin antagonist, honokiol, has been discovered from Magnolia grandiflora. It can negatively mediate the growth of breast cancer cells by inhibiting leptin-induced epithelial-mesenchymal transition (EMT) and mammosphere formation along with a reduction in the expression of stemness factors (Avtanski et al., 2015). Apart from that, resveratrol has also been reported to reduce leptin expression from isolated rat adipocytes (Szkudelska et al., 2009). This finding provides great insight into the potential of plant-derived bioactive compounds as one of the treatment strategies of $\mathrm{PCa}$.

With these insights, the therapeutic potential of plant phytochemicals has been gaining more research attention. One such plant that has sparked great research interest is Andrographis paniculata (AP). AP is an herbaceous plant that is most commonly recognized as the King of Bitter, Kalmegh, or Hempedu Bumi (Mishra et al., 2007). Traditionally, AP has been used to treat ailments such as fever, inflammation, viral and bacterial infections, and upper respiratory tract infection. It has also been used as an agent in the modulation of the immune system (Chao et al., 2011; Saxena et al., 2010). As a result, many discoveries have been made on the features of AP. Within the context of this review, AP has been found to inhibit the growth of cancer cells (Suriyo et al., 2014) and some components of MetS (Islam, 2017). Therefore, AP is an herb with high potential for the treatment of $\mathrm{PCa}-\mathrm{MetS}$ codisease.

\section{METHODOLOGY}

The literature for this review was conducted by searching various scientific electronic databases including Google Scholar, PubMed, Web of Science, SciFinder, Science Direct, American Chemical Society (ACS) Publications, Elsevier, and Wiley Online Library. Keywords used during the search were "AP" OR "Phytochemical" OR "Isolation" OR "PCa" OR "MetS" OR "Diabetes mellitus" OR "Hyperglycemia" OR "Hypertension" OR "Obesity" OR "Triglyceride" OR "Adipokine" OR "Cytokine". Occasionally, these keywords were combined using the 'AND' search function to generate more specific and refined search results. Additional information was derived from other literature sources (books, journals, and thesis written in English). To provide the most current overview of the topic, the search was restricted to include sources published from 2000 onward. Only when extremely necessary to support the discussion of the review, earlier sources were included. The review emphasizes the pathological relationship between MetS components and $\mathrm{PCa}$. Then, bioactive phytochemicals isolated from AP were studied as one of the promising agents to intervene in the disease relationship. Whenever possible, the mechanism of action of the bioactive compounds was also reviewed and discussed.

\section{RESULT \& DISCUSSION}

\section{Key component relationship between MetS and PCa}

MetS is comprised of high adiposity, hypertension, dyslipidemia, and hyperglycemia that are suspected to play a significant role in the worsening of PCa prognosis (Figure 3). In men with dyslipidemia, a $9 \%$ increase in recurrence risk has been observed for every $10 \mathrm{mg} / \mathrm{dl}$ increase in cholesterol level (Allott et al., 2014) and with elevated serum triglycerides, increased risk of recurrence after radical prostatectomy has also been noted. Moreover, Wright et al. (2013) reported that those with elevated glucose $(\geq 100 \mathrm{mg} / \mathrm{dl})$ had a $50 \%$ increased risk of recurrence compared to those with a normal glucose level $(<100 \mathrm{mg} / \mathrm{dl})$. As a result, glucose levels at the time of $\mathrm{PCa}$ diagnosis are suggested to be an independent predictor of $\mathrm{PCa}$ recurrence. These findings suggest that there is some relationship between MetS with $\mathrm{PCa}$ development that warrants our attention. The following section discusses the key components linking MetS with PCa based on a thorough literature search.

\section{Leptin}

The core contributor of MetS is high adiposity. One of the physiological functions of adipocytes is the secretion of essential adipokines for regular systemic maintenance. For instance, leptin is required for the maintenance of energy homeostasis and in the balancing of body weight. Its deficiency or genetic defects in the components of the leptin signaling pathways can cause obesity (Zhou and Rui, 2013). However, in a pathological setting, leptin can pose deleterious effects in PCa development (Fig. 1).

An in vitro study revealed that long-term exposure to leptin can enhance the growth of all main PCa cell lines (LNCaP, DU145, and PC-3) (Noda et al., 2015), where androgen-insensitive cells, DU145, and PC-3 show a stronger proliferative response (Hoda et al., 2012). Leptin also induces the expression of vascular endothelial growth factor (VEGF), transforming growth factor- $\beta 1$ (TGF- $\beta 1$ ), and basic fibroblast growth factor in DU145 and PC-3 cells, stimulating cell survival, proliferation, and angiogenesis (Frankenberry et al., 2004).

Leptin can influence estrogen metabolism and causes an increase in the expression of estrogen receptor (ER)- $\alpha$ and a decrease in ER- $\beta$ (Habib et al., 2015). At the same time, it can

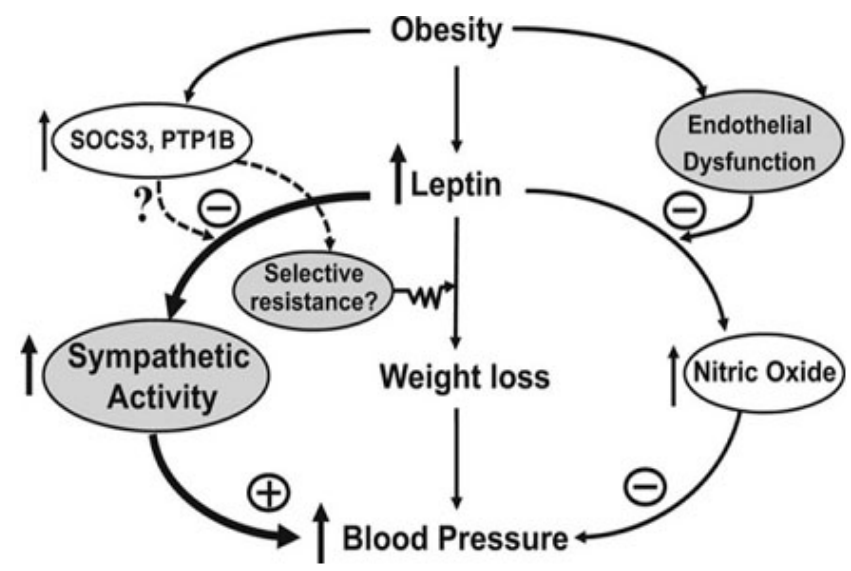

Figure 1. The role of leptin in the development of hypertension (Hall et al., 2015). 
also induce cellular migration of human PCa cells via upregulation of integrin and intracellular signal transduction (Huang et al., 2011). Obese mice injected with murine androgen-insensitive $\mathrm{PCa}$ cell line RM-1 developed larger tumors and had stronger Ki-67 staining (Ribeiro et al., 2010).

\section{Tumor necrosis factor- $\alpha(T N F-\alpha)$}

Adipocytes are also responsible for the secretion of TNF- $\alpha$. They are needed to promote tumor apoptosis, enhance vascular permeability to allow passage of drugs to the tumor sites, and inhibit angiogenesis at a high concentration (Zidi et al., 2010). TNF- $\alpha$ has also been reported to inhibit neovascularization, induce apoptosis of PCa cells, and stimulate antitumor immunity (Tse et al., 2012).

Paradoxically, an experiment conducted on transgenic adenocarcinoma of the mouse prostate mice suggested that elevated TNF- $\alpha$ correlates with higher mortality (Xu et al., 2015), suggesting TNF- $\alpha$ as one of the mediators to PCa. Its effect on other cancer cells, such as breast (Ma et al., 2017) and colorectal (De Simone et al., 2015), have also been reported. Simultaneously, there is evidence that it stimulates tumor angiogenesis, is involved in the initiation of PCa from an androgen-dependent to a castrationresistant state, and plays a role in EMT plasticity. Nevertheless, through meta-analysis, a recent study found that the dual effect of TNF- $\alpha$ on PCa is due to gene polymorphism (Ma et al., 2014).

\section{Interleukin-6 (IL-6)}

IL-6 functions in the regulation of the immune system, the nervous system, liver regeneration, and the metabolic control of the body (Rose-John, 2012). However, in people suffering from obesity, the IL-6 level is higher than usual to the point that it becomes deleterious (Popko et al., 2010). As it is one of the major inflammatory markers, its high concentration could gravely cause other problems. People with MetS are reported to have a higher inflammatory status, leading to other complications such as higher oxidative stress (Chen et al., 2012a) and cancer (Braun et al., 2011).

During PCa carcinogenesis, IL-6 and its receptors are elevated (Azevedo et al., 2011). In patients with metastatic tumors, IL-6 acts as a chemoattractant. The expression of excessive IL-6 in the lung, liver, or brain may attract the circulating tumor cells (Knüpfer and Preiss, 2008). Moreover, IL-6 can shift from a paracrine growth inhibitor to an autocrine growth stimulator in PCa cells, supporting its role in castration-resistant prostate cancer (CRPC) development. At an elevated level, resistance toward chemotherapy is predictive (Bonuccelli et al., 2014).

Elevated levels of IL-6 also stimulate hyperactivation of JAK/STAT3 signaling, which is often associated with poor treatment outcomes (Johnson et al., 2018). IL-6 signaling can also activate ERK1/2 signaling, leading to resistance to chemotherapy and immune-evasive phenotype in several cancer cells, including PCa (Salaroglio et al., 2019). The phosphoinositide 3-kinase (PI3K) signaling pathway is also activated by IL-6 in many cancers, causing cellular growth, survival, and proliferation. Overexpression of PI3K isoforms is also a cause for relapse and therapy resistance (Kim et al., 2019). IL-6 also may be involved in the metastatic process of PCa through the regulation of EMT (Rojas et al., 2011).

\section{Micro-RNA $301 a(m i R-301 a)$}

The elevated glucose level also has been known to increase the expression of miR-301a in PCa cells, thereby promoting G1/S cell cycle transition and accelerating cell proliferation (Li et al., 2019). The overexpression of miR-301a may also activate the invasion/migration of PCa cells (Damodaran et al., 2016). Also, high levels of miR-301a (above the median) were associated with an increased risk of biochemical recurrence (Nam et al., 2016). Due to its differential expression in PCa and benign samples, it has been utilized as a marker for differentiating whether a sample is cancerous or not. Its expression has been reported to be significantly higher in both serum and tumor tissue in patients with $\mathrm{PCa}$ compared to patients with benign prostatic hyperplasia (BPH). Furthermore, the expression of miR-301a in prostatectomy specimens correlated with an increased Gleason score (Kolluru et al., 2018).

\section{$E M T$}

Hyperglycemia could also modulate EMT by decreasing the E-cadherin level and increasing the $\mathrm{N}$-cadherin level (Li et al., 2016). Loss of E-cadherin facilitates dissociation of cancer cells from the tumor mass (origin site) and promotes tumor metastasis (Putzke et al., 2011). Patients with hyperglycemia showed a decreased E-cadherin/N-cadherin $(\mathrm{CDH} 1 / \mathrm{CDH} 2)$ ratio in prostate tissue, an indication of EMT (Franko et al., 2020).

Mature adipocyte cells also have been reported to secrete TGF- $\beta 1$ (El-Hattab et al., 2020). In the hyperglycemic state, TGF- $\beta 1$ signaling hyperactivation is eventually causing a reduction in E-cadherin expression (Rahn et al., 2018). This hormone has been described to affect the $\mathrm{CDH} 1 / \mathrm{CDH} 2$ ratio through PI3K/AKT/mTOR and Smad signaling (Luo et al., 2019).

\section{Matrix metalloproteinases (MMPs)}

At increased glucose concentrations, increased gene expression levels of MMPs have been detected (Franko et al., 2020). Additionally, a high glucose ( $25 \mathrm{mM})$ level has been known to induce the activity of the collagenase (MMP-1) and gelatinase (MMP-2) (Death et al., 2003). Elevated MMP activity promotes PCa progression not only by facilitating metastasis (Fig. 2) but also by profoundly impacting multiple steps of cell proliferation, apoptosis, angiogenesis, and EMT (Gong et al., 2014). A report from Trudel et al. (2003) also indicated that both malignant and normal prostate cells express MMP-2, but higher levels of MMP-2 expression in malignant prostate glands were noted compared to its normal counterpart. Prostate tumor-derived MMP-3 has also contributed to metastatic tumor growth in the bone, both in vitro and in vivo (Frieling et al., 2020).

\section{Dyslipidemia}

Dyslipidemia is also somewhat related to the pathogenesis of PCa. Low high-density lipoprotein cholesterol (HDL-C) level was found to be a risk and prognostic factor of $\mathrm{PCa}$ in several epidemiologic studies, although the overall linkage between HDL and $\mathrm{PCa}$ has not been definitively established (Kotani et al., 2013). In a study conducted among Chinese people with PCa, the level of low-density lipoprotein cholesterol (LDL-C) and total cholesterol was significantly higher and the HDL-C level is much lower (Zhao et al., 2017). Also, high triglyceride levels 
were reported to correlate well with a higher incidence of $\mathrm{PCa}$, especially in patients aged $\geq 60$ years. This group also tends to present with a higher Gleason score of $\geq 8$ (Hayashi et al., 2012). A retrospective study on 843 radical prostatectomy patients revealed that elevated serum triglycerides were associated with an increased risk of PCa recurrence (Allott et al., 2014). The mechanisms on how dyslipidemia correlates with PCa growth are still not yet elucidated. Some of the current meta-analyses concluded that the relationship is either not related (Cheng et al., 2019) or

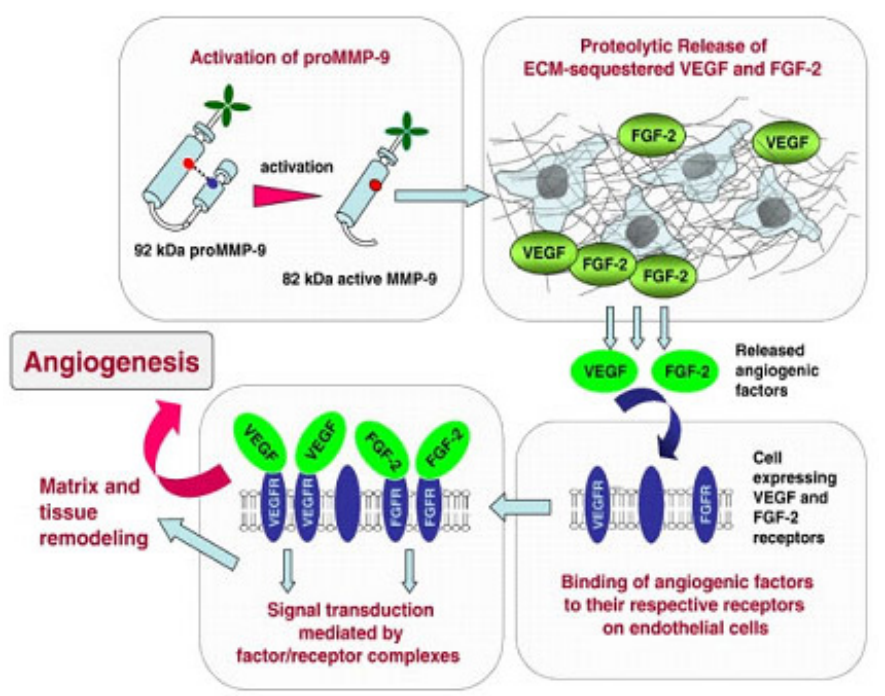

Figure 2. The action and relationship of VEGF and MMP-9 in the metastasis of cancer cells (Deryugina and Quigley, 2010). even inversely related (Ulmer et al., 2009). Perhaps, the role of lipid only comes into play during stress situations. For example, under hypoxic conditions, significantly higher proliferation was observed in PCa cells following reoxygenation associated with rapid use of accumulated lipids (Schlaepfer et al., 2015).

\section{AP and its isolates as a potential agent to combat MetS-PCa codisease}

AP is an herbaceous plant that is commonly known as Kalmegh (Bengali, Hindi), King of Bitter (English), Hempedu Bumi (Malay), Chuan Xin Lian (Chinese), Kirata (Sanskrit), and Shenshinren (Japanese) (Bone and Mills, 2013). It belongs to the family Achantaceae and it is ordinarily recognized based on its distinctive bitter taste. AP is known to be a native of India, Mainland China, and Taiwan. However, it can also be found in abundance in most Asian and south-east Asian countries (Hossain et al., 2014). Despite its exclusive favor in the tropical and subtropical regions (owing to the moist nature), cultivation attempts in the temperate regions of the globe have also been reported. The geographical locality of AP is wide ranging. It can grow healthily on roadsides, hill slopes, moist lands, gardens, farms, plane lands, waste ground, forest, and seashores (Hossain et al., 2014). Structurally, AP manifests the size of common shrubs with a height ranging from 30 to $110 \mathrm{~cm}$

The analysis of the crude alcohol extracts of the whole plant, leaf, and stem of AP revealed the presence of over 20 diterpenoids and over ten flavonoids. Among the most prominent phytochemicals, diterpenoid lactones stand out to be the most significant compound of AP, with andrographolide making up

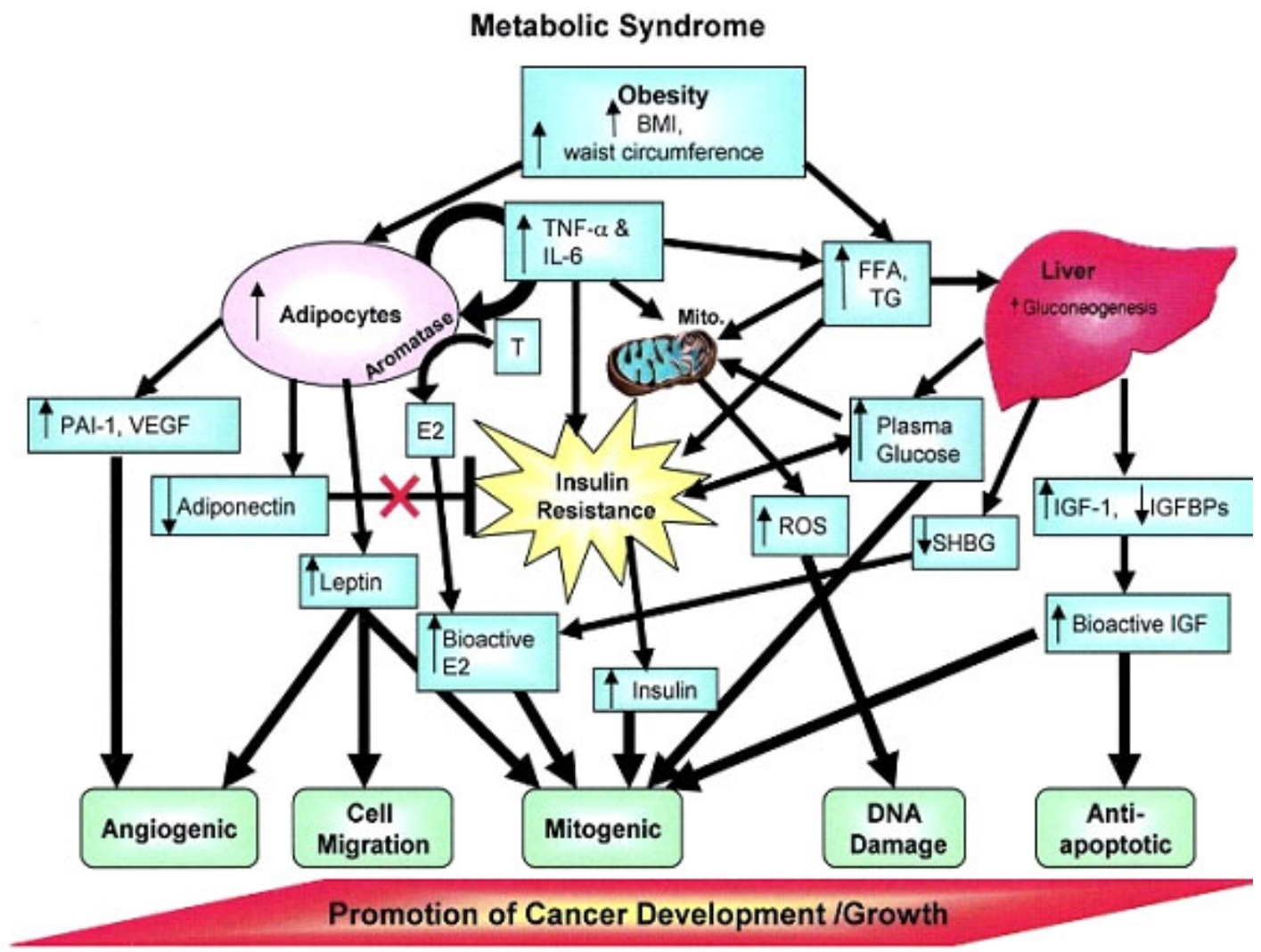

Figure 3. The relationship between MetS and cancer progression (Cowey and Hardy, 2006). 
about $4 \%, 0.8 \% \sim 1.2 \%$, and $0.5 \% \sim 6 \%$ in dried whole plant, stem, and leaf extracts, respectively (Chao and Lin, 2010). The other main diterpenoids are dehydroandrographolide, deoxyandrographolide, and neoandrographolide (Sriramaneni et al., 2019) with contents amounting to $1.12 \% \sim 1.97 \%$ (leaves) (Yanfang et al., 2006), $0.57 \%$, and $0.48 \%$, respectively (Xu et al., 2008).

These compounds are purported to reflect the therapeutic activities of AP owing to their significantly high amount. For this reason, several attempts have been undertaken by previous researchers to try to isolate and purify individual compounds for further exploration. For example, Chen et al. (2006) have reported successful isolations of 14 diterpenoids from AP using silica gel, Sephadex LH-20, ODS column chromatography, and highperformance liquid chromatography (HPLC). But the authors did not report any bioactivity of the isolated compounds. In another attempt, Wu et al. (2008) have successfully isolated 32 compounds including 14-deoxy-11,12-dihydroandrographolide, deoxyandrographolide, and neoandrographolide at high yield. After further testing, the author reported that 14-deoxy-11,12dihydroandrographolide exerts potential as a vasorelaxation agent that is important in the management of hypertension. In all reports, the goal of isolation is to obtain a high purity compound. This is crucial because studies conducted on the high purity compound are more reflective toward the plant's bioactivities. This is also a critical part of the quality control of herbal medicines. Table 1 lists the studies that have attempted the isolation of phytochemicals from AP.

In the arena of cancer research, AP has become one of the most studied herbal candidates for the treatment of several cancer malignancies including PCa. However, for MetS, the application of AP as one of the potential treatment candidates is still scarce. Perhaps, the disease itself is still not yet fully understood, which hinders this undertaking. Nevertheless, it has been agreed that MetS can be definitively described by the presence of at least three of the following criteria: (1) abdominal adiposity, (2) hyperglycemia, (3) hypertension, (4) high triglyceride, and (5) low HDL-C (Huang, 2009). In view of this understanding, AP could be directed to target these components individually to fight MetS.

When considering both diseases as unlinked illnesses, the role of AP as a potential mediator could be conferred with some degree of certainty based on reported literature. AP, through its isolated major diterpenoids, has been found to effectively inhibit the growth and progression of PCa cells. Geethangili et al. (2008) successfully isolated nine compounds from the aerial part of AP. When tested on a panel of cancer cell lines, almost all isolates exerted a prominent toxicity profile on Jurkat, PC-3, and Colon 205, except for HepG2. In another report, andrographolide was discovered to interfere with IL-6 signaling in both androgendependent and castration-resistant $\mathrm{PCa}$ cells, further inhibiting their progression (Chun et al., 2010). In an animal model, andrographolide was implicated in the decrease of tumor volume, MMP-11 expression, and blood vessel formation at the tumor mass (Forestier-Román et al., 2019).

In terms of MetS, AP has been reported to ameliorate hyperglycemia through inhibition of $\alpha$-glucosidase activity by andrographolide and several of its derivative (Dai et al., 2006), sensitization of the cell toward insulin by deoxyandrographolide (Arha et al., 2015), and functional protection of insulin-producing cells by a modified compound, andrographolide-lipoic acid conjugate (Zhang et al., 2009). Apart from that, andrographolide has been observed to effectively impede the obese manifestation by inhibiting lipid accumulation and improving serum lipid profile in high-fat diet-induced obese mice (Ding et al., 2014). The hypertensive animal model has also been reported to present with normal blood status after administration with 14-deoxy11,12, dihydroandrographolide (Yoopan et al., 2007).

However, when taking both diseases as a connected illness, there has been no report on the role of AP as a potential therapeutic agent. But, by understanding the relationship between the two diseases, the putative therapeutic target of AP could be structured based on literary reports with a prudent consideration of the possible limitations. As such, Table 2 presents the list of potential targets of AP and some of its isolates in the management of MetS-PCa codisease based on the evidence laid out by previous researchers. But, based on literature studies, a lot of the reports were conducted using andrographolide as the focal point. Studies using isolates such as neoandrographolide, deoxyandrographolide, and dihydroandrographolide are reported much less frequently.

\section{Enhancing bioavailability}

The curative action of AP and its isolates can only be achieved when it can be successfully delivered to the targeted

Table 1. Several attempts by previous researchers in the isolation of phytochemical constituents from AP.

\begin{tabular}{|c|c|c|}
\hline Source & Method & Isolated compound \\
\hline (Harjotaruno et al., 2007) & $\begin{array}{l}\text { AP extraction using methanol }>\text { partitioned with ethyl acetate }>\text { silica } \\
\text { column chromatography }\end{array}$ & Andrographolide \\
\hline (Kulyal et al., 2010) & $\begin{array}{l}\text { AP extraction using } 95 \% \text { ethanol }>\text { fractioned into chloroform and methanol } \\
>\text { methanol fraction was subjected to silica gel column chromatography with } \\
\text { methanol }(1.5 \%-21 \%) \text { in chloroform }>\text { repeated column chromatography for } \\
\text { purification }\end{array}$ & $\begin{array}{l}\text { Andrographolide, 14-deoxy-11,12-didehydroandrographolide, } \\
\text { 14-deoxyandrographolide, 3,14-dideoxyandrographolide, 14-deoxy- } \\
\text { 11-oxoandrographolide, 14-deoxy-12-hydroxyandrographolide, } \\
\text { neoandrographolide, andrographiside, and 14-deoxyandrographiside }\end{array}$ \\
\hline (Nugroho et al., 2014) & AP extraction using $90 \%$ ethanol $>$ fractionated at $1: 10$ (extraction-hexane) & Andrographolide-rich fraction \\
\hline (Syukri et al., 2016) & $\begin{array}{l}\text { AP extraction using ethanol }>\text { partitioned with ethyl acetate }>\text { column } \\
\text { chromatography using methanol : chloroform }(1: 9)\end{array}$ & Andrographolide \\
\hline (Sarkar et al., 2019) & $\begin{array}{l}\text { AP extraction using } 95 \% \text { methanol }>\text { silica gel }(100-200 \text { mesh) column } \\
\text { chromatography }>\text { elution with petroleum ether-chloroform }(1: 1 \text { and } 1: 4) \\
\text { and chloroform-methanol mixture with gradually increasing polarity }> \\
\text { crystallization }\end{array}$ & $\begin{array}{l}\text { 14-Deoxy-11,12-didehydroandrographolide, andrographolide, and } \\
\text { neoandrographolide }\end{array}$ \\
\hline $\begin{array}{l}\text { (Villedieu-Percheron } \\
\text { et al., 2019) }\end{array}$ & $\begin{array}{l}\text { AP extraction using } 100 \% \text { methanol }>\text { flash chromatography over silica gel } \\
\text { with elution gradient of methanol }(3 \%-15 \%) \text { in chloroform. }\end{array}$ & Andrographolide, dihydroandrographolide, and neoandrographiside \\
\hline
\end{tabular}


Table 2. Putative therapeutic target of AP in MetS-PCa codisease based on reported studies.

\begin{tabular}{l} 
MetS-PCa pathology \\
\hline TNF- $\alpha$ \\
Highly expressed by the \\
adipose tissue leading to \\
enhanced proliferation of \\
PCa.
\end{tabular}

\begin{tabular}{|c|c|}
\hline Source & Compound \\
\hline (Qin et al., 2006) & Andrographolide \\
\hline $\begin{array}{l}\text { (Thakur et al., } \\
\text { 2014) }\end{array}$ & Andrographolide \\
\hline $\begin{array}{l}\text { (Amaning } \\
\text { Danquah et al., } \\
2020 \text { ) }\end{array}$ & Andrographolide \\
\hline (Roy et al., 2010) & 14-Deoxyandrographolide \\
\hline
\end{tabular}

Mechanism of action

Reduction TNF-a at mRNA level.

Reduced production of TNF-a proteins in a concentrationdependent manner.

Both samples exert significant effect: blood TNF- $\alpha$ expressions in stressed rats were dose-dependently lowered by daily treatments.

In the cirrhotic lung, the TNF- $\alpha$ was highly expressed.

Treatment with andrographolide significantly decreased the serum concentration of TNF- $\alpha$.

(Roy et al., 2010) 14-Deoxyandrographolide

In vitro treatment of hepatocytes with this compound desensitizes the response of the cells toward TNF- $\alpha$.

\section{IL-6}

Autocrine and paracrine activity of IL-6 stimulate PCa cell growth.

(Chun et al., 2010) Andrographolide

(Zou et al., 2016) AP extract standardized at $1 \%$ mixture of andrographolide and dehydroandrographolide

(Al Batran et al., Andrographolide 2014)

(Liu et al., 2008) Andrograpanin

\section{Leptin}

Long-term exposure to elevated leptin from adipocyte can enhance the growth $\mathrm{PCa}$ cell lines (LNCaP, DU145, and PC-3) Leptin can activate cascades involved in cell survival particularly through the JAK2/STAT and PI3K/AKT pathways.

$$
\text { (Li et al., 2015) }
$$

Deoxyandrographolide

Andrographolide

\section{miR-301a}

Hyperglycemia has been

known to increase the expression of miR-301a in PCa cells, promoting cell cycle transition, proliferation, and invasion/migration of PCa cells by interfering with p21 and Smad4 expression (Li et al., 2018).

\section{EMT}

Hyperglycemia could modulate EMT in prostate tumors.
(Li et al., 2020) Andrographolide

(Yan et al., 2012) Andrographolide

(Shi et al., 2008) Andrographolide

$\begin{array}{ll}\text { (Li et al., 2020) } & \text { Andrographolide } \\ \text { (Liu et al., 2019) } & \text { Deoxyandrographolide } \\ \begin{array}{l}\text { (Kayastha } \text { et al., } \\ 2015)\end{array} & \text { Andrographolide }\end{array}$

The compound suppresses both IL-6 autocrine loop- and paracrine loop-induced cell signaling.

Administration significantly reduces the excessive production of cytokines and chemokines including IL-6 in a dosedependent manner.

Treatment on rabbit at two different doses (10 and $20 \mathrm{mg} / \mathrm{kg}$ ) exhibited a significant reduction in IL-6 level.

At $1.5 \mu \mathrm{M}$, andrograpanin significantly inhibited the expression of IL-6 from LPS-induced macrophage cells.

Almost complete inhibition of IL-6 was noted at $90 \mu \mathrm{M}$.

Andrographolide was able to significantly suppress STAT3 phosphorylation and subsequent nuclear translocation.

Achieved through suppression of JAK1/2 and interaction between STAT3 and gp130.

STAT3 suppression by andrographolide enhances the sensitivity of the cancer cells to doxorubicin.

Deoxyandrographolide induces autophagy cell death by inhibiting the PI3K/AKT/mTOR pathway.

Andrographolide inhibited hypoxia protein, HIF-1, in breast cancer cells by targeting the upstream PI3K/AKT pathway.

Andrographolide treatment caused a dose-dependent increase in the expression of cell cycle inhibitors p 21 and p27 in rheumatoid arthritis fibroblast-like synoviocytes (RAFLSs).

Cell cycle arrest at the G1/S phase was observed in Lovo cells after treatment with andrographolide at concentrations of 0-30 $\mu \mathrm{M}$

The expression of CDK inhibitor, p21, was significantly increased. andrographolide interfered with Smad4 nuclear translocation, repressing gene expression required for cell growth.

Andro inhibited TGF- $\beta 1$-induced EMT and EMT-related transcription factors in alveolar epithelial A549 cells.

Deoxyandrographolide treatment effectively rescued the EMT of osteosarcoma cells.

EMT markers, $\alpha$-SMA, fibronectin, and collagen IV, were significantly decreased after treatment with andrographolide in lens epithelial cells (LECs).
Treatment of human alveolar epithelial cells (AECs) with
Limitation

The experiment was conducted in murine peritoneal macrophages.

Rats in the study did not bear prostate tumors.

Rats in the study did not bear prostate tumors.

The study was conducted on a normal liver cell with the goal to inhibit cell death.

Mice studied did not present with the minimum criteria of MetS.

Mice in the study did not present with minimum criteria MetS and prostate tumor.

Secretion of the IL-6 was not confirmed to originate from adipocytes, and the rabbit did not bear prostate tumor.

Origin of IL-6 was not from adipocyte or PCa cell, and the animal did not bear prostate tumor.

The study was not conducted on PCa cells.

The study was not conducted on PCa cells.

The study was not conducted on PCa cells.

The study was not conducted on PCa cells.

The study was not conducted on PCa cells.

The study was not conducted on cancer cells.

The test was not conducted on PCa cells.

The test was not conducted on PCa cells.

The study was not conducted on cancer cells. 


\begin{tabular}{|c|c|c|c|c|}
\hline MetS-PCa pathology & Source & Compound & Mechanism of action & Limitation \\
\hline \multicolumn{5}{|l|}{ E-cadherin } \\
\hline \multirow{6}{*}{$\begin{array}{l}\text { In hyperglycemic condition, } \\
\text { the level of E-cadherin in } \\
\text { PCa cells is reduced. This } \\
\text { leads to EMT of the cancer } \\
\text { cells that eventually promote } \\
\text { metastasis and invasion. }\end{array}$} & \multirow[t]{2}{*}{$\begin{array}{l}\text { (Hsieh et al., } \\
\text { 2017) }\end{array}$} & \multirow[t]{2}{*}{ Dehydroandrographolide } & $\begin{array}{l}\text { Dehydroandrographolide significantly induced the expression } \\
\text { of E-cadherin in human oral cancer cell lines (SCC9). }\end{array}$ & \multirow{2}{*}{$\begin{array}{l}\text { The test was not conducted on } \\
\text { PCa cells and element of MetS } \\
\text { was not incorporated. }\end{array}$} \\
\hline & & & $\begin{array}{l}\text { EMT-related proteins, including Vimentin, Zo-1, Zeb-1, } \\
\text { Twist-1, Snail, Slug, N-cadherin, and } \beta \text {-cadherin, were } \\
\text { decreased. }\end{array}$ & \\
\hline & \multirow[t]{2}{*}{ (Xia et al., 2019) } & \multirow[t]{2}{*}{ Andrographolide } & $\begin{array}{l}\text { In the lung tissue of the mouse model, exposure to cigarette } \\
\text { smoke extract (CSE) decreased the level of E-cadherin. }\end{array}$ & \multirow{2}{*}{$\begin{array}{l}\text { The animal model did not confer } \\
\text { MetS and the target was not done } \\
\text { in tumor cells. }\end{array}$} \\
\hline & & & $\begin{array}{l}\text { Andrographolide blocked the decreases of E-cadherin levels } \\
\text { induced by CSE. }\end{array}$ & \\
\hline & \multirow[t]{2}{*}{ (Liu et al., 2017) } & \multirow[t]{2}{*}{ Andrographolide } & $\begin{array}{l}\text { Andrographolide sustained the expression of E-cadherin in } \\
\text { human osteosarcoma (bone cancer) cell, U-2 OS. }\end{array}$ & \multirow{2}{*}{$\begin{array}{l}\text { MetS microenvironment was not } \\
\text { introduced and the study was not } \\
\text { done on PCa cells. }\end{array}$} \\
\hline & & & $\begin{array}{l}\text { The treatment inhibits EMT, metastasis, and invasion of the } \\
\text { cancer cell. }\end{array}$ & \\
\hline \multicolumn{5}{|l|}{ TGF- $\beta 1$} \\
\hline \multirow[t]{4}{*}{$\begin{array}{l}\text { Hyperglycemia activates } \\
\text { the TGF- } \beta 1 \text { signaling that } \\
\text { eventually causes a reduction } \\
\text { in E-cadherin. }\end{array}$} & (Lin et al., 2018) & Andrographolide & $\begin{array}{l}\text { Andrographolide ameliorated both liver inflammation and } \\
\text { fibrosis through inhibiting the activation of the TLR } 4 / \mathrm{NF}-\mathrm{kB} \\
\text { and TGF- } \beta 1 / \mathrm{Smad} 2 \text { signaling pathways in hepatic stellate cells } \\
\text { (HSC). }\end{array}$ & $\begin{array}{l}\text { The study was not conducted in } \\
\text { MetS setting, and test on PCa } \\
\text { cells was not included. }\end{array}$ \\
\hline & \multirow[t]{3}{*}{ (Lee et al., 2010) } & \multirow[t]{3}{*}{$\begin{array}{l}\text { Andrographolide } \\
\text { and 14-deoxy-11,12- } \\
\text { didehydroandrographolide }\end{array}$} & $\begin{array}{l}\text { With high glucose treatment }(25 \mathrm{mM}) \text {, the secreted TGF- } \beta \\
\text { level was upregulated to } 2.5 \text { times in murine kidney cell line, } \\
\text { MES } 13 \text {. }\end{array}$ & \multirow[t]{3}{*}{$\begin{array}{l}\text { The study was not conducted on } \\
\text { cancer cells. }\end{array}$} \\
\hline & & & $\begin{array}{l}\text { Andrographolide and } 14 \text {-deoxy-11,12- } \\
\text { didehydroandrographolide showed significant effects in } \\
\text { reducing TGF- } \beta \text { levels secreted. }\end{array}$ & \\
\hline & & & 14-Deoxy-11,12-didehydroandrographolide is more potent. & \\
\hline \multicolumn{5}{|l|}{ MMPs } \\
\hline \multirow{4}{*}{$\begin{array}{l}\text { At increased glucose } \\
\text { concentration, increased gene } \\
\text { expression levels of MMPs } \\
\text { have been detected which } \\
\text { promotes PCa progression } \\
\text { and metastasis. }\end{array}$} & $\begin{array}{l}\text { (Zhang et al., } \\
\text { 2017) }\end{array}$ & Andrographolide & $\begin{array}{l}\text { Antiproliferation effects of andrographolide on the human } \\
\text { colorectal adenocarcinoma, SW620, cells were associated with } \\
\text { the inhibition of MMP-9 signaling activation. }\end{array}$ & $\begin{array}{l}\text { Study did not incorporate MetS } \\
\text { condition and without PCa cells. }\end{array}$ \\
\hline & (Shi et al., 2009) & Andrographolide & $\begin{array}{l}\text { Andrographolide inhibited dose-dependently the migration } \\
\text { and invasion of metastatic human colorectal adenocarcinoma, } \\
\text { Lovo cells. }\end{array}$ & $\begin{array}{l}\text { Study did not incorporate MetS } \\
\text { condition and without PCa cells. }\end{array}$ \\
\hline & & & $\begin{array}{l}\text { The treatment diminished the activity and the mRNA and } \\
\text { protein levels of MMP- } 7 \text {. }\end{array}$ & \\
\hline & (Chao et al., 2013) & Andrographolide & $\begin{array}{l}\text { Andrographolide dose-dependently inhibited TPA-induced } \\
\text { MMP-9 protein expression, enzyme activity, migration, and } \\
\text { invasion in MCF- } 7 \text { breast cancer cells. }\end{array}$ & $\begin{array}{l}\text { Study did not incorporate MetS } \\
\text { condition and without PCa cells. }\end{array}$ \\
\hline
\end{tabular}

site. But its low bioavailability has been a major challenge in drug delivery research. The bioavailability of AP was described to be only $2.67 \%$ and structural modification quickly takes place in duodenum and jejunum. Specifically, for andrographolide, low bioavailability is caused by high lipophilicity, low water solubility, and efflux by P-glycoprotein (Pandey and Rao, 2018). A low circulating concentration puts a limit on the therapeutic actions of the drug at the disease location.

One of the strategies that have been utilized is by incorporating the absorption enhancer. Andrographolide integrated into polymer solid dispersion (SD) formulation was reported to elevate its $C_{\max } /$ dose and the area under the curve (AUC)/dose by 3.7-fold and 3.0-fold, respectively (Yen et al., 2020). An SD utilizing silica, $\mathrm{SiO}_{2}$, was also fabricated by another researcher. In vitro testing revealed that the SD enhances the drug by improving its solubility and drug release profile (Zhang et al., 2016).

The strategy of using nanoparticlse has also been employed. There are several nanoparticle formulations that have been developed with fitting criteria to be used as a stable drug carrier such as liposome, solid-lipid nanoparticles (SLN), and nanostructured lipid carrier. Andrographolide-loaded herbosome incorporating soya-phosphatidylcholine has been formulated by Jain et al. (2013) in an effort to deliver its hepatoprotective properties. The authors reported better liver function and drug absorption in the rat model using the nanoparticle as compared to administration with free andrographolide. Graverini et al. (2018) have also attempted to deliver andrographolide to the brain as a strategy to treat neurodegenerative complications. However, the blood-brain barrier posed limited passage of the compound. By using SLN as the carrier, the compound was able to overcome the barrier. Semipurified andrographolide formulated into nano-phyto vesicle was also able to increase its bioavailability (Verma et al., 2020). To further enhance cellular uptake, the nanoparticles could also be improved by integrating the structure with cell-penetrating peptide (Chen et al., 2012b).

\section{CONCLUSION}

In conclusion, the link between MetS and PCa is mediated by a number of mechanisms including leptin, TNF- $\alpha$, IL- 6 , miR301a, EMT, and MMPs. AP and its isolates have great potential to intervene in these linkages. Previous studies have presented proof of concept on the capacity of AP and some of its isolates in 
targeting mechanisms involved in the MetS-PCa relationship. In particular, andrographolide has been reported repeatedly to have inhibitory capability in all relationships discussed. This review is hoped to open a new window of opportunity for AP as one of the treatment approaches for MetS-PCa codisease.

\section{AUTHOR CONTRIBUTIONS}

Conceptualization: Idris, M. K. H. Data curation: Idris, M. K. H. Supervision: Hasham, R. Writing - original draft: Idris, M. K. H. Writing - review and editing: Hasham, R.

\section{ACKNOWLEDGEMENTS}

This research was funded by the Higher Institution Centre of Excellence (HICoE) Grant (R.J130000.7846.4J266) from the Ministry of Education, Research University Grant (RUG) (9Q.J130000.2546.18H51) from UTM, and Malaysian Research University Network (MRUN) Grant (R.J130000.7851.4L885).

\section{CONFLICT OF INTEREST}

The author declares that there are no conflicts of interests.

\section{PUBLISHER'S NOTE}

This journal remains neutral with regard to jurisdictional claims in published institutional affiliation.

\section{REFERENCES}

Al Batran R, Al-Bayaty F, Al-Obaidi MMJ, Hussain SF, Mulok TZ. Evaluation of the effect of andrographolide on atherosclerotic rabbits induced by Porphyromonas gingivalis. Biomed Res Int, 2014; 2014:724718.

Allott EH, Howard LE, Cooperberg MR, Kane CJ, Aronson WJ, Terris MK, Amling CL, Freedland, SJ. Serum lipid profile and risk of prostate cancer recurrence: results from the SEARCH database. Cancer Epidemiol Biomarkers Prev, 2014; 23(11):2349.

Amaning Danquah C, Ativui S, Simon G, Bhakta S. Andrographolide, a major metabolite of Andrographis paniculata (Acanthaceae) shows antifibrotic and antioxidant properties. J Phytopharmacology, 2020; 9:12-7.

Arha D, Pandeti S, Mishra A, Srivastava SP, Srivastava AK, Narender T, Tamrakar AK. Deoxyandrographolide promotes glucose uptake through glucose transporter-4 translocation to plasma membrane in L6 myotubes and exerts antihyperglycemic effect in vivo. Eur J Pharmacol, 2015; 768:207-16.

Avtanski DB, Nagalingam A, Bonner MY, Arbiser JL, Saxena NK, Sharma D. Honokiol activates LKB1-miR-34a axis and antagonizes the oncogenic actions of leptin in breast cancer. Oncotarget, 2015; 6(30):29947-62.

Azevedo A, Cunha V, Teixeira AL, Medeiros R. IL-6/IL-6R as a potential key signaling pathway in prostate cancer development. World $\mathrm{J}$ Clin Oncol, 2011; 2(12):384-96.

Azizah AM, Hashimah B, Nirmal K, Siti Zubaidah AR, Puteri NA, Nabihah A, Sukumaran R, Balqis B, Nadia SMR, Sharifah SSS, Rahayu O, Nur Alham O, Azlina AA. Malaysia national cancer registry report (MNCR) 2012-2016 (No. MOH/P/IKN/05.19(AR)). Putrajaya, Malaysia: National Cancer Instituteo, 2019.

Bone K, Mills SY. Principles and practice of phytotherapy. 2nd edition, Churchill Livingstone, Saint Louis, MI, 2013; doi:10.1016/B9780-443-06992-5.00068-2

Bonuccelli G, Frank PG, Lisanti MP, Cinti C, Taranta M, Naldi I, Pardo JCT, Romero-Weaver AL, Howard CM, Durante M. Cutting edge therapies for cancer in the 21 st century. Bentham Science Publishers, Sharjah, UAE, 2014; doi: 10.2174/97816080588081140101

Braun S, Bitton-Worms K, LeRoith D. The link between the metabolic syndrome and cancer. Int J Biol Sci, 2011; 7(7):1003-15.
Catalano S, Leggio A, Barone I, De Marco R, Gelsomino L, Campana A, Malivindi R, Panza S, Giordano C, Liguori A, Bonofiglio D, Liguori A, Andò S. A novel leptin antagonist peptide inhibits breast cancer growth in vitro and in vivo. J Cell Mol Med, 2015; 19(5):1122-32.

Chao CY, Lii CK, Hsu YT, Lu CY, Liu KL, Li CC, Chen HW. Induction of heme oxygenase-1 and inhibition of TPA-induced matrix metalloproteinase- 9 expression by andrographolide in MCF-7 human breast cancer cells. Carcinogenesis, 2013; 34(8):1843-51.

Chao WW, Kuo YH, Hsieh SL, Lin BF. Inhibitory effects of ethyl acetate extract of Andrographis paniculata on NF-kB trans-activation activity and LPS-induced acute inflammation in mice. Evid Based Complement Alternat Med, 2011; 2011:9.

Chao WW, Lin BF. Isolation and identification of bioactive compounds in Andrographis paniculata (Chuanxinlian). Chin Med, 2010; 5(1):17.

Chen LX, Qu GX, Qiu F. Studies on diterpenoids from Andrographis paniculata]. Zhongguo Zhong yao za zhi, 2006; 31(19): 1594-7.

Chen R, Ren S, Yiu MK, Fai NC, Cheng WS, Ian LH, Naito S, Matsuda T, Kehinde E, Kural A, Chiu JY, Umbas R, Wei Q, Shi X, Zhou L, Huang J, Huang Y, Xie L, Ma L, Yin C, Xu D, Xu K, Ye Z, Liu C, Ye D, Gao X, Fu Q, Hou J, Yuan J, He D, Pan T, Ding Q, Jin F, Shi B, Wang G, Liu X, Wang D, Shen Z, Kong X, Xu W, Deng Y, Xia H, Cohen AN, Gao X, Xu C, Sun Y. Prostate cancer in Asia: a collaborative report. Asian J Urol, 2014; 1(1):15-29.

Chen SJ, Yen $\mathrm{CH}$, Huang YC, Lee BJ, Hsia S, Lin PT. Relationships between inflammation, adiponectin, and oxidative stress in metabolic syndrome. PLoS One, 2012a; 7(9):e45693.

Chen Y, Yuan L, Zhou L, Zhang ZH, Cao W, Wu Q. Effect of cell-penetrating peptide-coated nanostructured lipid carriers on the oral absorption of tripterine. Int J Nanomedicine, 2012b; 7:4581-91.

Cheng S, Zheng Q, Ding G, Li G. Influence of serum total cholesterol, LDL, HDL, and triglyceride on prostate cancer recurrence after radical prostatectomy. Cancer Manag Res, 2019; 11:6651-61.

Chun JY, Tummala R, Nadiminty N, Lou W, Liu C, Yang J, Evans CP, Zhou Q, Gao AC. Andrographolide, an herbal medicine, inhibits interleukin- 6 expression and suppresses prostate cancer cell growth. Genes Cancer, 2010; 1(8):868-76.

Cowey S, Hardy RW. The metabolic syndrome: a high-risk state for cancer? Am J Pathol, 2006; 169(5):1505-22.

Dai GF, Xu HW, Wang J, Liu FW, Liu HM. Studies on the novel $\alpha$-glucosidase inhibitory activity and structure - activity relationships for andrographolide analogues. Bioorg Med Chem Lett, 2006; 16:2710-3.

Damodaran C, Das TP, Papu John AMS, Suman S, Kolluru V, Morris TJ, Faber EN, Rai SN, Messer JC, Alatassi H, Ankem MK. miR301a expression: a prognostic marker for prostate cancer. Urol Oncol, 2016; 34(8):336.e313-20.

De Simone V, Franze E, Ronchetti G, Colantoni A, Fantini, M, Di Fusco D, Sica G, Sileri P, MacDonald T, Pallone F. Th17-type cytokines, IL-6 and TNF- $\alpha$ synergistically activate STAT3 and NF-kB to promote colorectal cancer cell growth. Oncogene, 2015; 34(27):3493-503.

Death AK, Fisher EJ, McGrath KC, Yue DK. High glucose alters matrix metalloproteinase expression in two key vascular cells: potentia impact on atherosclerosis in diabetes. Atherosclerosis, 2003; 168(2):263-9.

Deryugina EI, Quigley JP. Pleiotropic roles of matrix metalloproteinases in tumor angiogenesis: contrasting, overlapping and compensatory functions. Biochim Biophys Acta Mol Cell Res, 2010; 1803(1):103-20.

Ding L, Li J, Song B, Xiao X, Huang W, Zhang B, Tang X, Qi M, Yang Q, Yang Q, Yang L, Wang, Z. Andrographolide prevents high-fat diet-induced obesity in C57BL/6 mice by suppressing the sterol regulatory element-binding protein pathway. J Pharmacol Exp Ther, 2014; 351(2):474.

El-Hattab MY, Nagumo Y, Gourronc FA, Klingelhutz AJ, Ankrum JA, Sander EA. Human adipocyte conditioned medium promotes in vitro fibroblast conversion to myofibroblasts. Sci Rep, 2020; 10(1):10286.

Esposito K, Chiodini P, Capuano A, Bellastella G, Maiorino MI, Parretta E, Lenzi A, Giugliano D. Effect of metabolic syndrome and 
its components on prostate cancer risk: meta-analysis. J Endocrinol Invest, 2013; 36(2):132-9.

Ferlay J, Colombet M, Soerjomataram I, Dyba T, Randi G, Bettio M, Gavin A, Visser O, Bray F. Cancer incidence and mortality patterns in Europe: estimates for 40 countries and 25 major cancers in 2018. Eur J Cancer, 2018; 103:356-87.

Forestier-Román IS, López-Rivas A, Sánchez-Vázquez MM, Rohena-Rivera K, Nieves-Burgos G, Ortiz-Zuazaga H, Torres-Ramos CA, Martínez-Ferrer M. Andrographolide induces DNA damage in prostate cancer cells. Oncotarget, 2019; 10(10):1085-101.

Frankenberry KA, Somasundar P, McFadden DW, Vona-Davis LC. Leptin induces cell migration and the expression of growth factors in human prostate cancer cells. Am J Surg, 2004; 188(5):560-5.

Franko A, Berti L, Hennenlotter J, Rausch S, Scharpf MO, Angelis MHD, Stenzl A, Peter A, Birkenfeld AL, Lutz SZ, Häring HU, Heni $\mathrm{M}$. Increased expressions of matrix metalloproteinases (MMPs) in prostate cancer tissues of men with type 2 diabetes. Biomedicines, 2020; 8(11):507.

Frieling JS, Li T, Tauro M, Lynch CC. Prostate cancer-derived MMP-3 controls intrinsic cell growth and extrinsic angiogenesis. Neoplasia, 2020; 22(10):511-21.

Geethangili M, Rao YK, Fang SH, Tzeng YM. Cytotoxic constituents from Andrographis paniculata induce cell cycle arrest in jurkat cells. Phytother Res, 2008; 22(10):1336-41.

Gong Y, Chippada-Venkata UD, Oh WK. Roles of matrix metalloproteinases and their natural inhibitors in prostate cancer progression. Cancers, 2014; 6(3):1298-327.

Graverini G, Piazzini V, Landucci E, Pantano D, Nardiello P, Casamenti F, Pellegrini-Giampietro DE, Bilia AR, Bergonzi MC. Solid lipid nanoparticles for delivery of andrographolide across the blood-brain barrier: in vitro and in vivo evaluation. Colloids Surf B Biointerfaces, 2018; 161:302-13.

Habib CN, Al-Abd AM, Tolba MF, Khalifa AE, Khedr A, Mosli HA, Abdel-Naim AB. Leptin influences estrogen metabolism and accelerates prostate cell proliferation. Life Sci, 2015; 121:10-5.

Hall JE, Carmo JMD, Silva AAD, Wang Z, Hall ME. Obesityinduced hypertension. Circ Res, 2015; 116(6):991-1006.

Harjotaruno S, Widyawaruyanti A, Sismindari S, Zaini NC. Apoptosis inducing effect of andrographolide on TF-47 human breast cancer cell line. Afr J Tradit Complement Altern Med, 2007; 4(3):345-51.

Hayashi N, Matsushima M, Yamamoto T, Sasaki H, Takahashi $\mathrm{H}$, Egawa S. The impact of hypertriglyceridemia on prostate cancer development in patients aged $\geq 60$ years. BJU Int, 2012; 109(4):515-9.

Hoda MR, Theil G, Mohammed N, Fischer K, Fornara P. The adipocyte-derived hormone leptin has proliferative actions on androgenresistant prostate cancer cells linking obesity to advanced stages of prostate cancer. J Oncol, 2012; 2012:280386.

Hossain MS, Urbi Z, Sule A, Rahman KMH. Andrographis paniculata (Burm. f.) Wall. ex Nees: a review of ethnobotany, phytochemistry, and pharmacology. Sci World J, 2014; 2014:28.

Hsieh MJ, Chen JC, Yang WE, Chien SY, Chen MK, Lo YS, Hsi YT, Chuang YC, Lin CC, Yang SF. Dehydroandrographolide inhibits oral cancer cell migration and invasion through NF- $\mathrm{KB}-$, AP-1-, and SP1-modulated matrix metalloproteinase-2 inhibition. Biochem Pharmacol, 2017; 130:10-20.

Hsieh MJ, Lin CW, Chiou HL, Yang SF, Chen MK. Dehydroandrographolide, an iNOS inhibitor, extracted from Andrographis paniculata (Burm.f.) Nees, induces autophagy in human oral cancer cells. Oncotarget, 2015; 6(31):30831-49.

Huang CY, Yu HS, Lai TY, Yeh YL, Su CC, Hsu HH, Tsai FJ, Tsai $\mathrm{CH}, \mathrm{Wu} \mathrm{HC}$, Tang $\mathrm{CH}$. Leptin increases motility and integrin up-regulation in human prostate cancer cells. J Cell Physiol, 2011; 226(5):1274-82.

Huang PL. A comprehensive definition for metabolic syndrome. Dis Model Mech, 2009; 2(5-6):231-7.

Islam MT. Andrographolide, a new hope in the prevention and treatment of metabolic syndrome. Front Pharmacol, 2017; 8:571.

Jain PK, Khurana N, Pounikar Y, Gajbhiye A, Kharya MD. Enhancement of absorption and hepatoprotective potential through soya- phosphatidylcholine-andrographolide vesicular system. J Liposome Res, 2013; 23(2):110-8.

Johnson DE, O'Keefe RA, Grandis JR. Targeting the IL-6/ JAK/STAT3 signalling axis in cancer. Nature reviews. Clin Oncol, 2018; 15(4):234-48.

Kayastha F, Johar K, Gajjar D, Arora A, Madhu H, Ganatra D, Vasavada A. Andrographolide suppresses epithelial mesenchymal transition by inhibition of MAPK signalling pathway in lens epithelial cells. J Biosci, 2015; 40(2):313-24.

Kim JH, Kim WS, Park C. Interleukin-6 mediates resistance to PI3K-pathway-targeted therapy in lymphoma. BMC Cancer, 2019; 19(1):936-6.

Knüpfer H, Preiss R. sIL-6R: more than an agonist? Immunol Cell Biol, 2008; 86(1):87-91.

Kolluru V, Chandrasekaran B, Tyagi A, Dervishi A, Ankem M, Yan X, Maiying K, Alatassi H, Shaheen SP, Messer, JC, Edwards A, Haddad A, Damodaran C. miR-301a expression: diagnostic and prognostic marker for prostate cancer. Urol Oncol, 2018; 36(11):503.e509-15.

Kotani K, Sekine Y, Ishikawa S, Ikpot IZ, Suzuki K, Remaley AT. High-density lipoprotein and orostate cancer: an overview. J Epidemiol, 2013; 23(5):313-9.

Kulyal P, Tiwari U, Shukla A, Gaur A. Chemical constituents isolated from Andrographis paniculata. Indian J Chem, 2010; 49B:356-9.

Lee MJ, Rao YK, Chen K, Lee YC, Chung YS, Tzeng YM. Andrographolide and 14-deoxy-11,12-didehydroandrographolide from Andrographis paniculata attenuate high glucose-induced fibrosis and apoptosis in murine renal mesangeal cell lines. J Ethnopharmacol, 2010; 132(2):497-505.

Li J, Liu J, Yue W, Xu K, Cai W, Cui F, Li Z, Wang W, He J. Andrographolide attenuates epithelial-mesenchymal transition induced by TGF- $\beta 1$ in alveolar epithelial cells. J Cell Mol Med, 2020a; 24(18):10501-11.

Li J, Zhang C, Jiang H, Cheng, J. Andrographolide inhibits hypoxia-inducible factor-1 through phosphatidylinositol 3-kinase/AKT pathway and suppresses breast cancer growth. OncoTargets Ther, 2015; 8:427-35.

Li W, Zhang L, Chen X, Jiang Z, Zong L, Ma Q. Hyperglycemia promotes the epithelial-mesenchymal transition of pancreatic cancer via hydrogen peroxide. Oxid Med Cell Longev, 2016; $2016: 5190314$

Li W, Zhang X, Sang H, Zhou Y, Shang C, Wang Y, Zhu, H. Effects of hyperglycemia on the progression of tumor diseases. J Exp Clin Cancer Res, 2019; 38(1):327.

Li X, Li J, Cai Y, Peng S, Wang J, Xiao Z, Wang Y, Tao Y, Li J, Leng Q, Wu D, Yang S, Ji Z, Han Y, Li L, Gao X, Zeng C, Wen X. Hyperglycaemia-induced miR-301a promotes cell proliferation by repressing p21 and Smad4 in prostate cancer. Cancer Lett, 2018; 418: $211-20$.

Lin L, Li R, Cai M, Huang J, Huang W, Guo Y, Yang L, Yang G, Lan T, Zhu K. Andrographolide ameliorates liver fibrosis in mice: involvement of TLR4/NF- $\kappa$ B and TGF- $\beta 1 / \mathrm{Smad} 2$ signaling pathways. Oxid Med Cell Longev, 2018; 2018:7808656.

Liu J, Wang ZT, Ge BX. Andrograpanin, isolated from Andrographis paniculata, exhibits anti-inflammatory property in lipopolysaccharide-induced macrophage cells through down-regulating the p38 MAPKs signaling pathways. Int Immunopharmacol, 2008; 8(7):951-8

Liu X, Fan Y, Xie J, Zhang L, Li L, Wang Z. Dehydroandrographolide inhibits osteosarcoma cell growth and metastasis by targeting SATB2-mediated EMT. Anticancer Agents Med Chem, 2019; 19(14):1728-36.

Liu Y, Zhang Y, Zou J, Yan L, Yu X, Lu P, Wu X, Li Q, Gu $\mathrm{R}, \mathrm{Zhu}, \mathrm{D}$. Andrographolide induces autophagic cell death and inhibits invasion and metastasis of human osteosarcoma cells in an autophagydependent manner. Cell Physiol Biochem, 2017; 44(4):1396-410.

Luo Y, Ren Z, Du B, Xing S, Huang S, Li Y, Lei Z, Li D, Chen H, Huang Y, Wei G. Structure identification of viceninII extracted from Dendrobium officinale and the teversal of TGF- $\beta 1$-induced epithelialmesenchymal transition in lung adenocarcinoma cells through TGF- $\beta / \mathrm{Smad}$ and PI3K/Akt/mTOR signaling pathways. Molecules, 2019; 24(1):144. 
Ma L, Zhao J, Li T, He Y, Wang J, Xie L, Qin X, Li S. Association between Tumor necrosis factor- $\alpha$ gene polymorphisms and prostate cancer risk: a meta-analysis. Diagn Pathol, 2014; 9(1):74.

Ma Y, Ren Y, Dai ZJ, Wu CJ, Ji YH, Xu J. IL-6, IL-8 and TNF- $\alpha$ levels correlate with disease stage in breast cancer patients. Adv Clin Exp Med, 2017; 26(3):421-6.

Mishra SK, Sangwan NS, Sangwan RS. Plant review Andrographis paniculata (Kalmegh): a review. Pharmacogn Rev, 2007; 1(2):283-98.

Nam R, Benatar T, Wallis C, Amemiya Y, Yang W, Garbens A, Naeim M, Sherman C, Sugar L, Seth A. MiR-301a regulates E-cadherin expression and is predictive of prostate cancer recurrence. Prostate, 2016; 76(10):869-84.

Noda T, Kikugawa T, Tanji N, Miura N, Asai S, Higashiyama S, Yokoyama M. Long-term exposure to leptin enhances the growth of prostate cancer cells. Int J Oncol, 2015; 46(4):1535-42.

Nugroho AE, Rais IR, Setiawan I, Pratiwi PY, Hadibarata T, Tegar M, Pramono S. Pancreatic effect of andrographolide isolated from Andrographis paniculata (Burm. f.) Nees. Pak J Biol Sci, 2014; 17(1):2231 .

Pakzad R, Mohammadian-Hafshejani A, Ghoncheh M, Pakzad I, Salehiniya $H$. The incidence and mortality of prostate cancer and its relationship with development in Asia. Prostate Int, 2015; 3(4):135-40.

Pandey G, Rao C. Andrographolide: its pharmacology, natural bioavailability and current approaches to increase its content in Andrographis paniculata. Int J Complement Altern Med, 2018; 11(6):355-60.

Popko K, Gorska E, Stelmaszczyk-Emmel A, Plywaczewski R, Stoklosa A, Gorecka D, Pyrzak B, Demkow U. Proinflammatory cytokines IL- 6 and TNF- $\alpha$ and the development of inflammation in obese subjects. Eur J Med Res, 2010; 15(2):120.

Putzke AP, Ventura AP, Bailey AM, Akture C, Opoku-Ansah J, Celiktaş M, Hwang MS, Darling DS, Coleman IM, Nelson PS, Nguyen HM, Corey E, Tewari M, Morrissey C, Vessella RL, Knudsen BS. Metastatic progression of prostate cancer and e-cadherin regulation by zeb1 and SRC family kinases. Am J Pathol, 2011; 179(1):400-10.

Qin LH, Kong L, Shi G, Wang ZT, Ge BX. Andrographolide inhibits the production of TNF- $\alpha$ and interleukin-12 in lipopolysaccharidestimulated macrophages: role of mitogen-activated protein kinases. Biol Pharm Bull, 2006; 29:220-4.

Rahn S, Zimmermann V, Viol F, Knaack H, Stemmer K, Peters L, Lenk L, Ungefroren H, Saur D, Schäfer H, Helm O, Sebens S. Diabetes as risk factor for pancreatic cancer: hyperglycemia promotes epithelialmesenchymal-transition and stem cell properties in pancreatic ductal epithelial cells. Cancer Lett, 2018; 415:129-50.

Ribeiro AM, Andrade S, Pinho F, Monteiro JD, Costa M, Lopes C, Aguas AP, Monteiro MP. Prostate cancer cell proliferation and angiogenesis in different obese mice models. Int J Exp Pathol, 2010; 91(4):374-86.

Rojas A, Liu G, Coleman I, Nelson PS, Zhang M, Dash R, Fisher PB, Plymate SR, Wu JD. IL-6 promotes prostate tumorigenesis and progression through autocrine cross-activation of IGF-IR. Oncogene, 2011; 30(20):2345-55.

Rose-John S. IL-6 trans-signaling via the soluble IL-6 receptor: importance for the pro-inflammatory activities of IL-6. Int J Biol Sci, 2012; 8(9):1237-47.

Roy DN, Mandal S, Sen G, Mukhopadhyay S, Biswas T. 14-Deoxyandrographolide desensitizes hepatocytes to tumour necrosis factor-alpha-induced apoptosis through calcium-dependent tumour necrosis factor receptor superfamily member $1 \mathrm{~A}$ release via the NO/cGMP pathway. Br J Pharmacol, 2010; 160(7):1823-43.

Salaroglio IC, Mungo E, Gazzano E, Kopecka J, Riganti C. ERK is a pivotal player of chemo-immune-resistance in cancer. Int J Mol Sci, 2019; 20(10):2505.

Sarkar S, Gopal P, Chakraborty B, Paul M, Chowdhury C, Paul S. 14-Deoxy-11,12-didehydroandrographolide: a novel compound isolated from Andrographis paniculata nees. Induces robust apoptosis in leukemic cells. Pharmacogn Mag, 2019; 15(62):135-43.

Saxena RC, Singh R, Kumar P, Yadav SC, Negi MPS, Saxena VS, Joshua AJ, Vijayabalaji V, Goudar KS, Venkateshwarlu K, Amit A. A randomized double blind placebo controlled clinical evaluation of extract of Andrographis paniculata (KalmCold ${ }^{\mathrm{TM}}$ ) in patients with uncomplicated upper respiratory tract infection. Phytomedicine, 2010; 17(3):178-85.

Schlaepfer I, Nambiar D, Ramteke A, Kumar R, Dhar D, Agarwal C, Bergman B, Graner M, Maroni, P, Singh R, Agarwal R, Deep G. Hypoxia induces triglycerides accumulation in prostate cancer cells and extracellular vesicles supporting growth and invasiveness following reoxygenation. Oncotarget, 2015; 6(26):22836-56.

Shi MD, Lin HH, Chiang TA, Tsai LY, Tsai SM, Lee YC, Chen $\mathrm{JH}$. Andrographolide could inhibit human colorectal carcinoma Lovo cells migration and invasion via down-regulation of MMP-7 expression. Chem Biol Interact, 2009; 180(3):344-52.

Shi MD, Lin HH, Lee YC, Chao JK, Lin RA, Chen JH. Inhibition of cell-cycle progression in human colorectal carcinoma Lovo cells by andrographolide. Chem Biol Interact, 2008; 174(3):201-10.

Sim HG, Cheng CWS. Changing demography of prostate cancer in Asia. Eur J Cancer, 2005; 41(6):834-45.

Sriramaneni R, Sadikun A, Shivashekaregowda N, Venkatappa A, Asmawi M. Identification of bioactive diterpenoid lactones using nuclear magnetic resonance from Andrographis paniculata. Pharmacogn Res, 2019; 11(2):121-6.

Suriyo T, Pholphana N, Rangkadilok N, Thiantanawat A, Watcharasit P, Satayavivad J. Andrographis paniculata extracts and major constituent diterpenoids inhibit growth of intrahepatic cholangiocarcinoma cells by inducing cell cycle arrest and apoptosis. Planta Med, 2014 80(07):533-43.

Syukri Y, Martien R, Lukitaningsih E, Nugroho A. Quantification of andrographolide isolated from Andrographis paniculata nees obtained from traditional market in yogyakarta using validated HPLC. Indones $\mathrm{J}$ Chem, 2016; 16:190-7.

Szkudelska K, Nogowski L, Szkudelski T. The inhibitory effect of resveratrol on leptin secretion from rat adipocytes. Eur J Clin Invest, 2009; 39(10):899-905.

Thakur AK, Soni UK, Rai G, Chatterjee SS, Kumar V. Protective effects of Andrographis paniculata extract and pure andrographolide against chronic stress-triggered pathologies in rats. Cell Mol Neurobiol, 2014; 34(8):1111-21.

Trudel D, Fradet Y, Meyer F, Harel F, Têtu B. Significance of MMP-2 expression in prostate cancer. Cancer Res, 2003; 63(23):8511.

Tse BWC, Scott KF, Russell PJ. Paradoxical roles of tumour necrosis factor-alpha in prostate cancer biology. Prostate Cancer, 2012; 2012:128965

Ulmer H, Borena W, Rapp K, Klenk J, Strasak A, Diem G, Concin H, Nagel G. Serum triglyceride concentrations and cancer risk in a large cohort study in Austria. Br J Cancer, 2009; 101(7):1202-6.

Verma VK, Zaman MK, Verma S, Verma SK, Sarwa, KK. Role of semi-purified andrographolide from Andrographis paniculata extract as nano-phytovesicular carrier for enhancing oral absorption and hypoglycemic activity. Chin Herb Med, 2020; 12(2):142-55.

Villedieu-Percheron E, Ferreira V, Campos JF, Destandau E, Pichon C, Berteina-Raboin, S. Quantitative determination of andrographolide and related compounds in Andrographis paniculata extracts and biological evaluation of their anti-inflammatory activity. Foods, 2019; 8(12):683.

Wright JL, Plymate SR, Porter MP, Gore JL, Lin DW, Hu E, Zeliadt SB. Hyperglycemia and prostate cancer recurrence in men treated for localized prostate cancer. Prostate Cancer Prostatic Dis, 2013 16(2):204-8.

Wu TS, Chern HJ, Damu AG, Kuo PC, Su CR, Lee EJ, Teng CM. Flavonoids and ent-labdane diterpenoids from Andrographis paniculata and their antiplatelet aggregatory and vasorelaxing effects. J Asian Nat Prod Res, 2008; 10(1):17-24. 
Xia H, Xue J, Xu H, Lin M, Shi M, Sun Q, Xiao T, Dai X, Wu L, Li J, Xiang Q, Tang H, Bian Q, Liu, Q. Andrographolide antagonizes the cigarette smoke-induced epithelial-mesenchymal transition and pulmonary dysfunction through anti-inflammatory inhibiting HOTAIR. Toxicology, 2019; 422:84-94.

Xiang YZ, Xiong H, Cui ZL, Jiang SB, Xia QH, Zhao Y, Li $\mathrm{GB}$, Jin $\mathrm{XB}$. The association between metabolic syndrome and the risk of prostate cancer, high-grade prostate cancer, advanced prostate cancer, prostate cancer-specific mortality and biochemical recurrence. J Exp Clin Cancer Res, 2013; 32(1):9.

$\mathrm{Xu} \mathrm{H}, \mathrm{Hu} \mathrm{MB}$, Bai PD, Zhu WH, Liu SH, Hou JY, Xiong ZQ, Ding Q, Jiang HW. Proinflammatory cytokines in prostate cancer development and progression promoted by high-fat diet. Biomed Res Int, 2015; 2015:249741.

$\mathrm{Xu} \mathrm{T}$, Pan J, Zhao L. Simultaneous determination of four andrographolides in Andrographis paniculata nees by silver ion reversedphase high-performance liquid chromatography. J Chromatogr Sci, 2008; 46(8):747-50.

Yan J, Chen Y, He C, Yang ZZ, Lü C, Chen XS. Andrographolide induces cell cycle arrest and apoptosis in human rheumatoid arthritis fibroblast-like synoviocytes. Cell Biol Toxicol, 2012; 28(1):47-56.

Yanfang Z, Xingping L, Zongde Z, Liren C, Yongmin L. Simultaneousdetermination of andrographolide and dehydroandrographolide in Andrographis paniculata and Chinese medicinal preparations by microemulsion electrokinetic chromatography. J Pharm Biomed Anal, 2006; 40(1):157-61.

Yen CC, Liang YK, Cheng CP, Hsu MC, Wu YT. Oral bioavailability enhancement and anti-fatigue assessment of the andrographolide loaded solid dispersion. Int J Mol Sci, 2020; 21(7):2506.

Yoopan N, Thisoda P, Rangkadilok N, Sahasitiwat S, Pholphana N, Ruchirawat S, Satayavivad J. Cardiovascular effects of 14-Deoxy-11,12didehydroandrographolide and Andrographis paniculata Extracts. Planta Med, 2007; 73(06):503-11.

Zhang D, Lin J, Zhang F, Han X, Han L, Yang M, Zou W. Preparation and evaluation of andrographolide solid dispersion vectored by silicon dioxide. Pharmacogn Mag, 2016; 12(Suppl 2):S245-52.
Zhang R, Zhao J, Xu J, Jiao DX, Wang J, Gong ZQ, Jia JH. Andrographolide suppresses proliferation of human colon cancer SW620 cells through the TLR4/NF-kB/MMP-9 signaling pathway. Oncol Lett, 2017; 14(4):4305-10.

Zhang Z, Jiang J, Yu P, Zeng X, Larrick JW, Wang Y. Hypoglycemic and beta cell protective effects of andrographolide analogue for diabetes treatment. J Transl Med, 2009; 7:62.

Zhao R, Cheng G, Wang B, Qin C, Liu Y, Pan Y, Wang J, Hua L, Zhu W, Wang Z. BMI and serum lipid parameters predict increasing risk and aggressive prostate cancer in Chinese people. Oncotarget, 2017; 8(39):66051-60.

Zhou J, Ong CN, Hur GM, Shen HM. Inhibition of the JAKSTAT3 pathway by andrographolide enhances chemosensitivity of cancer cells to doxorubicin. Biochem Pharmacol, 2010; 79(9):1242-50.

Zhou Y, Rui L. Leptin signaling and leptin resistance. Front Med, 2013; 7(2):207-22.

Zidi I, Mestiri S, Bartegi A, Amor NB. TNF- $\alpha$ and its inhibitors in cancer. Med Oncol, 2010; 27(2):185-98.

Zou W, Xiao Z, Wen X, Luo J, Chen S, Cheng Z, Xiang D, Hu J, He J. The anti-inflammatory effect of Andrographis paniculata (Burm. f.) Nees on pelvic inflammatory disease in rats through down-regulation of the NF-кB pathway. BMC Complement Altern Med, 2016; 16(1):483.

\section{How to cite this article:}

Idris MKH, Hasham R. Preventive potential of Andrographis paniculata-derived compounds in metabolic syndromeassociated prostate cancer: A narrative review on the mechanism of action. J Appl Pharm Sci, 2021; 11(08): 167-177. 